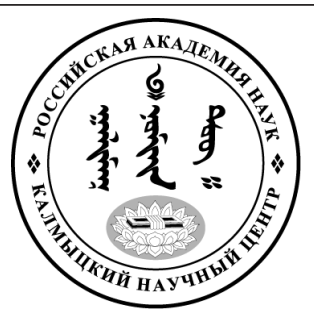

Published in the Russian Federation

Oriental Studies (Previous Name: Bulletin of the Kalmyk Institute

for Humanities of the Russian Academy of Sciences)

Has been issued as a journal since 2008

ISSN: 2619-0990; E-ISSN: 2619-1008

Is. 5, pp. 771-786, 2019

DOI: $10.22162 / 2619-0990-2019-45-5-771-786$

Journal homepage: https://kigiran.elpub.ru

УДК 94(470+571)18/1917

\title{
Правовые основы землевладения и землепользования переселенцев в Семиречье в конце XIX - начале XX в.
}

Фиалка Нуруевна Мийманбаева ${ }^{1}$ Александр Нармаевич Команджаев², Евгений Александрович Команджаев ${ }^{3}$

${ }^{1}$ Казахский национальный университет им. Аль-Фараби (д. 71, пр. Аль-Фараби, 050040 Алматы, Республика Казахстан)

кандидат исторических наук, доцент кафедры всемирной истории, историографии и источниковедения

ORCID: 0000-0002-8900-7262. E-mail: m.fialka58@mail.ru

2 ФГБОУ ВО «Калмыцкий государственный университет им. Б. Б. Городовикова» (д. 11, ул. Пушкина, 358000 Элиста, Российская Федерация)

доктор исторических наук, профессор, заведующий кафедрой истории России, документоведения и архивоведения

ORCID: 0000-0002-7064-7315. E-mail: kalmhistory@yandex.ru

3 ФГБОУ ВО «Калмыцкий государственный университет им. Б. Б. Городовикова» (д. 11, ул. Пушкина, 358000 Элиста, Российская Федерация)

кандидат юридических наук, доцент, заведующий кафедрой теории и истории государства и права

ORCID: 0000-0002-4542-8786. E-mail: kalmhistory@yandex.ru

Аннотация. Введение. Исследование проблемы формирования русских крестьянских поселений в Семиречье в конце XIX - начале XX в. вызвано ее недостаточной изученностью. Помимо этого актуальность вопроса объясняется необходимостью учета в условиях современной миграционной политики республик бывшего СССР богатого исторического опыта складывания многонационального населения в национальных регионах России позднеимперского периода. Цель исследования - проанализировать историю формирования правовых основ русской крестьянской колонизации в Семиречье и землепользования переселенцев в конце XIX - начале XX в. Материаль и методы. Содержание статьи основано на применении как общенаучных, так и конкретно-исторических методов, в том числе сравнительно-исторического метода и междисциплинарного подхода. В работе использованы материалы центральных архивов России, Казахстана и Узбекистана, значительную долю которых составила делопроизводственная документация. Источниками исследования являются также труды дореволюционных авторов, которые в силу своего служебного положения занимались организацией крестьянских переселений в Семиречье и оставили ценные свидетельства. Результатьы. Правительственная и стихийная крестьянская колонизация Семиречья являлась сложным процессом, вызывавшим трудности в определении правового статуса переселенческого землепользования. Эта правовая неопределенность создавала в регионе различные типы крестьянских поселений — старожиль- 
ческие села, новоселия и самовольные поселки, имевших свои особенности и, соответственно, неодинаковый правовой статус. Это было связано со сложностью земельных отношений в Семиречье и недостаточной определенностью нормативной базы крестьянского землепользования в регионе. Bblводbl. В статье отмечается, что владельческие права кочевых народов Семиречья на землю были оформлены российской администрацией рядом нормативных актов в ходе административных реформ 1867-1868 гг. Эти земли объявлялись государственными, переданными в бессрочное общественное пользование кочевникам. В силу этого переселенцам пришлось проблему землепользования решать в основном самостоятельно, арендуя земли у кочевников и используя другие механизмы. В ряде случаев администрация была вынуждена процесс расселения переселенцев с частичным решением их поземельного статуса реализовать административной волей. Однако в силу сложности вопроса о наделении переселенцев землей остро встал вопрос о необходимости проведения землеотводных работ в регионе в начале XX в., но они так и не были завершены в дореволюционное время.

Ключевые слова: Российская империя, Туркестан, Семиречье, колонизация, крестьянство, переселение, землевладение, землепользование, столыпинская аграрная реформа, землеотводные работы

Благодарность. Исследование выполнено в рамках внутривузовского гранта ФГБОУ ВО «Калмыцкий государственный университет им. Б. Б. Городовикова» «Особенности управления национальными территориями в дореволюционной России», 2019 г.

Для цитирования: Мийманбаева Ф. Н., Команджаев А. Н., Команджаев Е. А. Правовые основы землевладения и землепользования переселенцев в Семиречье в конце XIX - начале XX в. Oriental Studies. 2019; (5): 771-786. DOI: 10.22162/2619-0990-2019-45-5-771-786.

UDC 94(470+571)18/1917

\title{
Immigrants in Semirechye (Zhetysu): Legal Basis for Land Tenure and Land Use in the Late $19^{\text {th }}-$ Early $20^{\text {th }}$ Centuries
}

\author{
Fyalka N. Miymanbaeva ${ }^{1}$, Alexander N. Komandzhaev ${ }^{2}$, Evgeny A. Komandzhaev $^{3}$ \\ ${ }^{1}$ Al-Farabi Kazakh National University (71, Al-Farabi Ave., Almaty 050040, Republic of Kazakhstan) \\ Cand. Sc. (History), Associate Professor, Department of World History, Historiography and Source \\ Studies \\ ORCID: 0000-0002-8900-7262.E-mail:m.fialka58@mail.ru \\ ${ }^{2}$ Gorodovikov Kalmyk State University (11, Pushkin St., Elista 358000, Russian Federation) \\ Dr. Sc. (History), Head of Department of Russian History, Archives and Records Management \\ ORCID: 0000-0002-7064-7315.E-mail: kalmhistory@yandex.ru \\ ${ }^{3}$ Gorodovikov Kalmyk State University (11, Pushkin St., Elista 358000, Russian Federation) \\ Cand. Sc. (Law), Head of Department of Theory and History of State and Law \\ ORCID: 0000-0002-4542-8786. E-mail: kalmhistory@yandex.ru
}

\begin{abstract}
Introduction. The relevance of addressing the issue of land management by peasant migrants in the national peripheries of the Russian Empire is associated not only with the need to take into account interethnic and religious relations in the regions and provide a detailed analysis of external and internal migration flows, but also with insufficient study of the topic. Land relations were especially difficult in all Russia's regions with prevailing nomadic populations: Semirechye (Zhetysu), Lower Volga region, Ciscaucasian steppes, etc. The greatest contribution to the study of the question was made by pre-revolutionary researchers who, as a rule, were government officials obliged to deal with the resettlement (Rumyantsev P. P., Kaufman A. A., Palen K. K., etc.). In the Soviet period, the topic was examined in detail by N. E. Bekmakhanova. Currently, the study of the problem has become actual due to the need to clarify and reassess some of the established past views. Goals. The paper seeks to analyze the legal status of migrant peasants in the region inhabited by nomadic peoples and their land management practices. Materials and Methods. The work
\end{abstract}


involves a wide range of legislative and statistical sources, eyewitness accounts and materials from central archives of Russia, Kazakhstan and Uzbekistan, revealing the complex nature of legal land system definitions of immigrant peasants. Results. During the government-initiated and spontaneous colonization of Semirechye in the late $19^{\text {th }}$ and early $20^{\text {th }}$ centuries, various types of rural peasant settlements - old-timed, newly emerged and self-willed ones - were established, which required legal land management regulation. Since administrative agencies in many cases found it difficult to determine legal statuses of peasant lands in Semirechye, the migrants had to solve the problem of land use on their own entering into negotiations with nomadic communities, directly renting land from the latter under different conditions. This made it even more difficult to finally resolve the issue of legal regulation of land tenure and land use. Conclusions. Local administrations - due to the complexity of land relations between immigrants and nomads, poor vision of a complete picture of land management in the region, lack of land for the growing population and the difficulty of conducting Stolypin land management - were able to start collecting information about land management in Semirechye and actually conduct land allocation only in the beginning of the $20^{\text {th }}$ century. The outbreak of World War I and subsequent social upheavals made it impossible to complete the determination of legal foundations of resettlement land management in Semirechye in the pre-revolutionary period.

Keywords: Russian Empire, Turkestan, Semirechye, colonization, peasantry, resettlement, land tenure, land use, Stolypin agrarian reforms, land allotment works

Acknowledgements: The reported study was granted by Gorodovikov Kalmyk State University, project name 'Administering National Territories in Pre-Revolutionary Russia: Specific Features', 2019.

For citation: Miymanbaeva F. N., Komandzhaev A. N., Komandzhaev E. A. Immigrants in Semirechye (Zhetysu): Legal Basis for Land Tenure and Land Use in the Late $19^{\text {th }}-$ Early $20^{\text {th }}$ Centuries. Oriental Studies. 2019; (5): 771-786. DOI: 10.22162/2619-0990-2019-45-5-771-786.

\section{Введение}

На современном этапе развития государственности Казахстана и России актуальным является изучение опыта политико-правового регулирования переселенческого вопроса в Российской империи. Анализ сложной практики решения вопросов землепользования и землевладения в дореволюционной России позволит увидеть перспективы правовых преобразований в земельном вопросе многонациональных государств. Указанная проблема относится к числу недостаточно изученных в историографии. Наибольший вклад в анализ проблемы внесли авторы дореволюционных работ, которые ввели в научный оборот значительный объем статистических материалов и оставили нам свои ценные наблюдения и заметки [Кауфман 1905; Пален 1910; Румянцев 1911; Шкапский 1907]. Как правило, они являлись чиновниками и по долгу службы занимались правовым и земельным обустройством переселенцев.

$\mathrm{B}$ советской историографии изучение проблемы обогатилось за счет использования большого количества архивного материала и расширения исследовательских задач [Бекмаханова 1986; Ильясов 1963; Сапелкин 1977]. Однако рамки марксистской методологии с ее классовым подходом не позволили представить всю сложность землеустройства русских переселенцев в регионах с кочевым населением. В современный период происходит переоценка прежних взглядов и уточнение устоявшихся положений. Исходя из степени изученности проблемы, авторы статьи ставят задачу анализа процесса определения правовых основ землеустройства русских крестьян-переселенцев в ходе формирования многонационального населения Семиречья в конце XIX - начале XX в.

Материалы и методы. В качестве источников привлечены материалы Российского государственного военно-исторического архива [РГВИА], Российского государственного исторического архива [РГИА], Центрального государственного архива Республики Узбекистан [ЦГА РУ], Центрального государственного архива Республики Казахстан [ЦГА РК]. Среди них следует особо выделить делопроизводственные документы и статистические материалы. К числу источников можно отне- 
сти работы дореволюционных исследователей по истории переселенческого движения, поскольку представленные ими материалы, наблюдения и заметки являются свидетельствами современников [Пален 1910]. Авторы также учли имеющийся историографический опыт своих предшественников, что позволило аргументировать выводы работы.

Решение исследовательских задач основано на принципах историзма и системного анализа, поскольку правовые вопросы переселения крестьян в Туркестанский край, а также вопросы землевладения и землепользования переселенцев рассматриваются как следствие социально-исторических условий, в формировании которых важную роль играли внутриполитические и внешние факторы.

Результаты. Для Российской империи второй половины XIX - начала XX в. жарактерна активизация переселенческой политики. Экономика российского государства испытывала потребность в источниках сырья и новых рынках сбыта продукции. Однако продвижение России в Среднюю Азию имело не только экономическую обусловленность. Среди других причин - военно-стратегические интересы Российской империи, связанные с желанием помешать Китаю и Англии закрепиться на своих границах. Для укрепления имперских окраин требовалось создать необходимую массу русского населения, которая стала бы опорой целостности российского государства в регионе. Немаловажное значение в этом процессе отводилось крестьянам-переселенцам, которые в сложившихся обстоятельствах превращались в проводников политики Российской империи на окраинах страны.

В соответствии с положениями «Об управлении Семиреченской и Сыр-Дарьинской областями» от 11 июля 1867 г. и «Об управлении в Уральской, Тургайской, Акмолинской и Семипалатинской областях» от 21 октября 1868 г. одним из ключевых законодательных решений российской администрации на пути к претворению земельной политики на территории Казахстана стало объявление всех казахских земель государственными, переданными в бессрочное пользование кочевникам. Согласно ст. 270 Положения об управлении Туркестанским краем государственные земли, занимаемые «киргизами», т. е. современными казахами и кыргызами, предоставлялись в бессрочное общественное пользование кочевников, т. е. без принятия особого закона не могли быть переданы русским переселенцам [РГВИА. Ф. 400. Оп. 1. Д. 3243. Л. 33].

Характеризуя поземельное устройство кочевников Семиреченской области в рассматриваемый период, Н. А. Аристов писал, что российские власти до введения административных реформ 1867-1868 гг. вмешивались в существовавшее ранее традиционное «поземельное владение киргиз только в двух случаях: во-первых, для разрешения возникавших между киргизами поземельных споров и для равномерного распределения земель между волостями и, во-вторых, для изъятия из владения и пользования киргизских земель, необходимых для учреждения казачьих, крестьянских и городских поселений» [Аристов 2003: 347]. Основным аспектом колонизации края являлся отвод земель под устройство казачьих и крестьянских поселений.

Вследствие завоевания Россией Южного Казахстана и Северной Киргизии в конце 60-х гг. XIX в. было образовано Туркестанское генерал-губернаторство. Правительство Российской империи в этот период укрепляло свое военное и политическое господство в приграничных районах Туркестана, способствуя тем самым переселению крестьян. А. А. Кауфман откровенно говорил, что «заселение окраин определялось почти всецело политическою потребностью, как способ упрочения в них русского господства» [Кауфман 1905: 197].

Повсеместный характер крестьянская колонизация приобретает после образования Туркестанского генерал-губернаторства, в состав которого вошла сформированная на основе Алатауского внешнего округа Семиреченская область. В 1867 г. генералгубернатор Туркестанского края К. П. Кауфман поручил начальнику Алатауского округа генерал-майору Г. А. Колпаковскому изыскать места «под новые казачьи и крестьянские поселения». Г. А. Колпаковский, к этому времени назначенный военным губернатором Семиреченской области, предложил план колонизации Семиречья [Кауфман 1905: 197].

Началом претворения этих планов стало землеустройство семиреченского казачества. При размещении казаков в Семиречье 
российские власти ориентировались на «Положение о Сибирском казачьем войске» от 5 декабря 1846 г., согласно которому размер надела на одного человека определялся в 30 десятин. Со временем, исходя из социально-экономических и геополитических особенностей данного региона, земельное обустройство семиреченских казаков приобрело свои отличия. 21 апреля 1869 г. вступило в силу Положение Военного совета «О поземельном устройстве казачьих станиц», которое окончательно утвердило для всех российских казаков норму земельного надела в 30 дес. и 10 дес. в войсковой запас «для обеспечения его безбедного существования» [Абдиров, Актамбердиева 2011: 109].

Согласно проекту Г. А. Колпаковского, предполагалось поселить по 50 семей крестьян в Токмаке, Пишпеке и на Иссык-Куле, а всего предусматривалось «... создание в пяти уездах области 34 крестьянских села на 1345 дворов и 47 мелких поселений при станционных пикетах на 470 дворов» [Далаева 2012: 201]. Всего планировалось переселить 1815 крестьянских семей.

В 1867 г. Г. А. Колпаковский пригласил из Воронежской губернии, где родился, несколько сот крестьянских семей. По сведениям П. П. Румянцева, начиная с 1869 г., в течение 70-х годов было образовано 28 селений. Всего по уездам, включая земли нынешнего Северного Кыргызстана, было образовано: в Лепсинском - 8, Копальском - 2, Верненском - 6, Пржевальском - 6, Пишпекском - 6 селений [Румянцев 1911: 210].

Переселенцы смогли быстро адаптироваться к существующим в регионе природным и социально-экономическим условиям. В короткие сроки удалось наладить свою экономическую жизнь, через ведение зернового хозяйства.

В 1869 г. на утверждение Туркестанскому генерал-губернатору Г. А. Колпаковским было представлено «Положение об устройстве в Семиреченской области сельских поселений». В данном Положении было прописано, что на каждого мужчину отводится по 30 десятин пригодной территории, из которых 15 формировало запас на случай естественного прироста населения. Для поселенцев, обосновывавшихся на территории почтовых трактов, земельный надел увеличивался до 15 десятин. Новоселы, согласно данному Положению, освобожда- лись от всех податей и повинностей на срок 15 лет. Исключение составляли те из них, которые селились на пикетах. В этом случае срок освобождения от податей и повинностей составлял 25 лет. Допустимый размер ссуды на семью не должен был превышать 100 руб. В действительности ссуды отпускались в значительно меньшем объеме или не выдавались вовсе. Нагляден пример: за период с 1870 по 1895 гг. 615 семьям было выдано 10000 руб. [Пален 1910: 8-9].

Для того чтобы крестьяне-переселенцы могли прописаться на новом месте, необходимо было представить два вида документов: увольнительное свидетельство и подписку об ознакомлении с местными законами и правилами. В случае, если переселенцы в течение года не осваивались в местах прописки, они подлежали принудительному выселению. Форма землепользования определялась общинная, без возможности выкупа участка в собственность. А. А. Кауфман отмечал: «Главнейшую основу колонизации на восток составляло земледельческое население, усеявшее край деревнями, без него казенная колонизация не имела бы поддержки и стерлась» [Кауфман 1905: 205].

В середине 70-Х гг. XIX в. в Семиречье назрела необходимость создания русских поселений. Проект Г. А. Колпаковского не был утвержден в законодательном порядке, но все же он был приведен в исполнение и действовал с некоторыми незначительными отступлениями до 1883 г. Однако большой наплыв переселенцев уже к середине 70-Х гг. XIX в. исчерпал все наличные для заселения земли. Впоследствии, в связи с началом переселения дунган и уйгуров из Западного Китая, норма крестьянского надела была уменьшена. В материалах ревизии Туркестанского края, осуществленной в начале XX в. под руководством сенатора К. К. Палена зафиксировано, что доля крестьянского надела в Семиреченском крае была снижена: в 1876 г. до 17 дес., а в 1883 г. - до 10 дес. [Сатенова 2019].

Российское правительство и местные органы власти, надеясь создать себе прочную опору, стремились заселить регион хозяйственно крепкими крестьянами. Чтобы добраться до нового места жительства, получить землю и обустроить свое хозяйство, переселенцы должны были быть достаточно состоятельными людьми. Малоимущим 
крестьянам было бы не под силу освоить тяжелую дорогу из Европейской России, которая требовала больших расходов, связанных с транспортировкой своего имущества, скота и прочего хозяйственного инвентаря. Следовательно, основная масса переселенцев у себя на родине являлись середняками [Мийманбаева 2002: 33]. Естественно, что в пути многие крестьяне разорялись, не добравшись даже до своего участка. Так, 36,7 \% семей, переселившихся в Туркестан с 1906 по 1913 гг, прибыли без всякого имущества, а 60,9 \% - без денег [Сапелкин 1977: 87]. Поэтому большое количество переселенцев, прибывших в край, терпели всевозможные тяготы и невзгоды, остро нуждались в помощи, но не получали ее. Местная администрация хотела освободиться от «ненадежных элементов», у которых не было ни денег, ни земли. Их не приписывали к участкам, надеясь, что таким образом бедные вернутся в свои прежние места поселения. Однако они не могли этого сделать из-за отсутствия средств и оказывали сопротивление властям. Местная администрация была вынуждена воздерживаться от выселения безземельных крестьян в места их прежнего проживания. Опасались этого и центральные органы власти.

Несмотря на большие масштабы переселения, из 100 семей, пересекших Урал, 15 возвращались на старое место, не прижившись на новом [Graham 1916: 153].

Министр внутренних дел в своем секретном циркуляре от 17 апреля 1895 г. за № 259 писал: «Нельзя ожидать пользы от обратного возвращения на родину отдельных крестьянских семейств, принявших переселение на собственный страх» [Пален 1910: 20]. В соответствии с данной инструкцией только некоторые из наиболее опасных людей подлежали выселению назад с разрешения министра внутренних дел.

Кроме необходимого земельного надела и избавления от податей и повинностей, переселенцам не приходилось ждать никакой иной поддержки от местной администрации. Как указывал военный начальник Семиреченской области, денежные пособия не давались специально для обеспечения «лучшего хозяйственного и нравственного состава колонистов» [Обзор 1884: 49]. Правительство умышленно создавало такие условия, которые способствовали бы водворе- нию хозяйственно-состоятельных крестьян, с расчетом на то, что при большом наделе земли они быстро смогут окулачиться.

Изнуренные тяжелым и длительным переездом, переселенцы стремились во что бы то ни стало получить землю. Возникший в результате массового переселения дефицит земли привел к тому, что переселенцы начинали захват земель, принадлежавших киргизам. Все это приводило к столкновениям между местным и пришлым населением. В первые годы колонизации киргизы отдавали свои земли без видимого сопротивления, хотя уже тогда колонизация ущемляла их интересы, лишая их лучших пахотных земель и пастбищ. Однако в дальнейшем трудности, связанные с изъятием земель, все более возрастали. К 1882 г., только по официальным данным, у кочевников Семиреченской области было изъято 160000 дес. земли [Забиров 1958: 151].

В 1883 г. Семиреченская область была выведена из состава Туркестанского генерал-губернаторства и включена в состав Степного генерал-губернаторства. В 1881 и 1883 гг. появляются новые проекты с целью упорядочения правил землевладения поселенцев и местного населения. Правила 1883 г. действовали вплоть до выхода переселенческого закона 1889 г. Проект правил был разработан в 1883 г. специальной комиссией, созванной в г. Верном. Суть его заключалась в следующем: 1) душевой надел крестьян-переселенцев и местного населения определялся в 10 дес. удобной земли, при этом полагалось не менее 4 дес. пахотной земли, из которых не менее 2-х дес., обеспеченных искусственным орошением; 2) русским переселенцам были предоставлены привилегии, установленные на общих основаниях: в течение 3 -х лет со времени причисления они освобождались от платежа оброчной подати, а от земского сбора - в половинном размере. Более того, переселенцы избавлялись на первые три года от несения натуральных земских повинностей [Забиров 1958: 153]. В правилах указывалось, что никаких пособий от казны на переселение и водворение в сельских поселениях области не отпускается, но в особо уважительных случаях (падеж скота, эпидемические болезни и т. п.) прибывшим в пределы области военным начальником выдаются ссуды из особого на этот пред- 
мет кредита [Обзор 1884: 52]. В отличие от Положения 1867 года, Положение 1883 года имело целью не привлечение крестьян, а упорядочение переселенческого дела. Тем не менее урезание льгот остановило переселение.

В течение 1868-1880 гг. в Семиречье переселилось 3324 семьи. 1225 семей были причислены к мещанскому сословию городов Семиречья, а остальные 2099 семей были поселены в крестьянских селениях. Кроме того, в крестьянские селения также были причислены 242 семьи из числа отставных и запасных нижних чинов [ЦГА РК. Ф. 19. Оп. 1. Д. 1171. Л. 110-111].

В конце 1880-х гг. царское правительство создает специальные структуры переселения на всех уровнях, систематически ведя учет мигрантов, направлявшихся в Азиатскую Россию. 13 июля 1889 г. было принято специальное «Положение о добровольном переселении сельских жителей и мещан на государственные земли и порядке причисления лиц означенных сословий». В данном Положении определены районы переселения в Семиреченской, Акмолинской и Семипалатинской областях, что значительно расширило возможности для потенциальных переселенцев. По распространении этого Положения на Семиреченскую область, по распоряжению МВД, она была закрыта для «для движения переселенцев» на 2 года, и областной администрацией начата была работа по поиску новых земель для переселенцев [ЦГА РК. Ф. 19. Оп. 1. Д. 1171. Л. 112].

С 90-х гг. XIX в. крестьянская колонизация стала широко распространенным явлением. Голод в начале 90-х гг. в центральных регионах России вызвал огромный приток переселенцев в Туркестанский регион, особенно в пределах границ Семиречья. Этот приток привел к еще большей путанице в действующих регламентах для переселенцев. Только в период с 1891 по 1892 гг. в Семиреченскую область прибыло 1769 семей, что составило $85 \%$ от общего числа мигрантов, прибывших в регион за предыдущие 13 лет [Шкапский 1907: 137].

Bсе эти переселенцы прибыли в регион без разрешения Министерства внутренних дел и без увольнительных приговоров из прежних мест проживания. Согласно закону 1889 г., все они подлежали выселению с места регистрации. Но местная администрация не сочла возможным применить этот закон против них, оказавшись беспомощной против такого потока переселенцев. Как и в ряде других случаев, правительство рано или поздно должно было признать крестьян-самовольцев. Первоначально они поселились на подготовленных для них земельных участках, далее - путем аренды земель у киргизов или захватнических действий с землей основывали свои хозяйства. Формирование так называемых самовольных сел относится к этому периоду. Инициативу в этом отношении задали переселенцы-иммигранты, прибывшие в Пишпекский уезд.

Недостаточная организация работы по переселению и конфискация больших площадей земли у кыргызского населения, вызвавшие естественное недовольство последних, вынудили местные власти обратиться к правительству с просьбой об официальном закрытии Туркестанского края для переселенцев [Ильясов 1963: 275].

Сразу после завоевания и открытия Семиреченской области в составе Туркестанского генерал-губернаторства еще в 60-70-е гг. XIX в. началась казачья колонизация Семиречья. В конце XIX в. крестьянское переселение в Семиреченскую область ставилось администрацией Туркестанского края в зависимость от решения вопроса о казачьей колонизации области. Положением Комитета министров от 3 марта 1895 г. было постановлено «произвести исследование казачьих земель по фактическому и бесспорному владению и определить, на какое количество естественно орошающихся земель следует засчитывать поливную десятину» [Бартольд 1963: 322].

В 1895 г было созвано специальное совещание (г. Омск) по вопросу дальнейшего водворения переселенцев в Семиреченскую область. Совещание выступило с просьбой к министерству внутренних дел о запрете переселения в область крестьян, якобы до «земельного устройства» киргизского населения [Ильясов 1963: 260]. Решение Совещания получило одобрение МВД, и распоряжением от 15 июня 1896 г. выдача разрешений на переселение в область была запрещена. Разрешение на переселение могло выдавать только Министерство внутренних дел. Законом от 7 декабря 1896 г. каждой 
семье разрешалось посылать ходоков в районы будущего переселения [Бекмаханова 1986: 155]. Возникает ходаческое движение. Прежде чем заселить территорию предполагаемого вселения, переселенцы отправляли «ходоков». Состав «ходоков» формировался из наиболее грамотной, предприимчивой и зажиточной части переселенцев. Ходаческое движение своей целью преследовало более близкое знакомство с ситуацией на новом месте. Только после этого, при их положительном мнении о месте вселения, принималось решение и происходило собственно переселение семьи или группы семей. Но, несмотря на законы, правительство продолжало ограничивать переселение.

Однако никакие меры не могли остановить переселенческого движения в Туркестан. В 1901-1902 гг. в область хлынула вторая большая волна переселенцев, которая по своим размерам превысила первую. Возникло самовольческое, стихийное переселение крестьян, длившееся до 1904 г. В 1902 г. прибыли переселенцы главным образом из западно-сибирских губерний и областей (Томской, Тобольской, Акмолинской и Семипалатинской) [ЦГА РК. Ф. 19. Оп. 1. Д. 1171. Л. 114-115].

Таким образом, в Семиречье назревал земельный кризис. Местные власти под видом «свободных земель» отбирали у киргизов земли, при этом захватывались лучшие пастбищные угодья без учета особенностей ведения животноводческого хозяйства, требовавшего больших земельных площадей.

В статистике поселки, образованные в Семиречье первыми переселенцами, называются «старожильческими». Всем старожильческим селениям, которые были образованы до 1905 г., вручались владенные записи. Так, С. И. Ильясов в своей статье отмечал, что во владенных записях приводились такие характеристики, как численность мужских душ, общее количество надельных земель, а также формы землепользования, суммы налогов и коллективная ответственность за полное и своевременное внесение их в казну [Ильясов 1963: 265].

По завершении льготного срока по уплате налогов поселок включался в общий налоговый список. С этого момента новопереселенческие поселки считались старожильческими. Между крестьянами происходило окончательное распределение закреплен- ных за селом запасных земельных участков. Для увеличения доходов казны льготные сроки постепенно сокращались. Население досрочно лишалось установленных законом прав, а государство освобождалось от тех незначительных обязанностей, которое оно брало на себя по устройству переселенцев. П. П. Румянцев отмечал: «И самовольцы-арендаторы и самовольцы-захватчики прежде, чем образовать на выборном месте новый поселок, устраивались обыкновенно на некоторое время в старожильческих селениях в качестве квартирантов, называемые старожителями «иногородние», «разночинцами», а по статистической терминологии - посторонними. Затем часть уходила в новые самовольческие поселки, а часть продолжала жить в старых селениях, арендуя землю у киргиз и русских старожил» [Румянцев 1911: 212].

О. А. Шкапский в журнале «Вопросы колонизации» дает описание, как формировались самовольческие селения. Так, крестьяне в количестве нескольких человек арендовывали небольшой участок земли на период до 30 лет. На этом участке они строили свои усадьбы. Таким путем образовались сёла Покровка и Свинячья выселка. Из описания О. А. Шкапского «...однако, надо заметить, что, во-первых, они не имеют своей надельной земли для пашен, сенокоса и выгона и все эти угодья арендуют у киргизов, платя аренды в Покровке по 5,5 рублей за десятину, а в Свинячьей выселке - по 4,7 рублей за десятину, а во-вторых, аренда усадебной земли признается администрацией незаконной. Покровцы вследствие этого испытали целый ряд гонений, а Свинячья выселка, не подвергаясь гонению со стороны администрации, подвергалась гонению со стороны старого селения Беловодского, богатые крестьяне которого лишились выгона для своих свиней, почему и дали такое название» [Шкапский 1907: 24].

По статье 126 Положения об управлении Степными областями кочевникам предоставлялось право сдавать в аренду лицам русского происхождения земли, находящиеся в пределах их зимовых стойбищ, сроком до 30 лет для земледелия и устройства промышленных заведений - фабрик, заводов, мельниц и других производств. Сдача земли в аренду могла производиться только по приговорам съездов волостных выборных. 
В 1900 г. Туркестанский генерал-губернатор обратился в правительство с ходатайством о распространении на коренные области Туркестана ст. 126 Степного Положения. Министр земледелия и государственных имуществ считал необходимым воздержаться от введения к применению данной статьи, так как полагал, что предоставление кочевникам права сдавать в аренду государственные земли могло бы дать им повод предъявлять на эти земли права собственности. Только в 1901 г. министерство разрешило применять данную статью к Туркестану, так как «таким образом создавалась возможность ненасильственным путем усилить русский элемент среди иноплеменного населения» [РГВИА. Ф. 400. Оп. 1. Д. 2652. Л. 15-15об.].

В любом новом месте, новом крае, где проходила русская крестьянская колонизация, очень быстро образовывалась крестьянская община. Общинная организация поддерживала и регулировала традиционное хозяйство и бытовой уклад жизни с его дуализмом коллективного и индивидуального владения. Сельская община играла важную роль в жизни населения, занимаясь всеми общими делами поселенцев. Селения получали наделы в общинное пользование, каждый двор имел определенные нормы надела, которыми пользовались до тех пор, пока имелся запасной фонд доселения. При полном использовании запасного фонда производилось перераспределение земельного массива, общины соблюдали известную равномерность сроков земельного распределения $-1,3,5,7,9$ лет. Так, в селении Сазановка Пржевальского уезда переделы земель осуществлялись обществом через каждые 4 года [РГИА. Ф. 391. Оп. 3. Д. 828. Л. 54об.]. Так как земли в селениях крестьян на первых порах было достаточно, то ее нередко переделяли не только по числу мужских душ, но даже по числу едоков [Логанов 1909: 64].

Переделы земли в условиях Семиречья наносили хозяйству крестьян большой вред, так как сроки их были весьма незначительны, и, таким образом, на общинных полях совершенно невозможны были посевы озимых и многолетних растений. Но независимо от этого селениям, особенно старожильческим, нарезались новые земли, удовлетворявшие запросы зажиточной части переселенцев. Необходимую кормовую тра- ву - люцерну — крестьяне на своих землях не сеяли, а пользовались для этих посевов арендой «киргизских» земель. Земля находилась в пользовании общины как единого целого. Права на землю сливались в общине в единое общее право, а не составляли простую совокупность прав ее отдельных членов. Права общины распространялись и на арендованную целым селением землю, так как почти все русское население Семиречья занималось земледелием на арендованной у «киргизов» земле. Арендуемые земли часто являлись основой хозяйства крестьян, в то время как отведенные в надел переселенцам земли, будучи вполне пригодны для земледелия, использовались менее интенсивно, чем это было возможно в соответствии с природными условиями.

Необходимо вспомнить, что основной, исконной формой русского землепользования было захватное, когда крестьянин занимал в понравившемся месте столько земли, сколько ему было нужно. Эту форму землепользования первые русские переселенцы и принесли в Туркестан. П. П. Румянцев писал: «Первые переселенцы захватывали земли, наиболее удобные и плодородные, и, таким образом, русские поселения располагались в подгорной культурной полосе и в предгорьях» [Румянцев 1911: 220]. Но так как в Туркестане земля была не частной, а государственной, переданной кочевникам в бессрочное пользование, переселенцам в конце концов пришлось ожидать официального наделения их землей, да и огромный поток переселенцев в начале XX в. привел к дефициту земли в Семиречье. В связи с этим захватная форма землепользования трансформировалась в уравнительную, с регулярными переделами по числу мужских душ. Следующей стадией землепользования была подворно-участковая форма. Г. Логанов писал, что, согласно действующим законам, казенные земли предоставлялись переселенцам в общинное или подворное бессрочное пользование. В коренных областях Туркестана, по закону 10 июня 1903 г. «Правила о добровольном переселении сельских обывателей и мещан на казенные земли в области Сыр-Дарьинскую, Ферганскую и Самаркандскую», орошаемые земли отводились переселенцам в подворно-участковое пользование, прочие же - в общественное, но на практике это осущест- 
влялось далеко не всегда. При составлении приговора о подворном или участковом пользовании землею, необходимо было придерживаться нижеследующих условий: 1) подворное или участковое хозяйство разрешалось лишь на заполненных переселенческих участках; 2) приговор о распределении земель между домохозяевами данного переселенческого участка должен был исходить от большинства - двух третей домохозяйств, имевших право голоса на сходе [Логанов 1909: 63].

По-видимому, появлению подворноучастковой формы землепользования способствовал, наряду с другими причинами, и дух крестьянского индивидуализма и предприимчивости. О таком хуторском хозяйстве свидетельствует приговор выборных Курмектинской волости Пржевальского уезда от 30 ноября 1910 г. о сдаче в аренду Федору Чурокаеву 60 десятин земли, в котором было оговорено, чтобы деньги за аренду вносились «в подать по нашему аулу в Пржевальское казначейство к 1 ноября ежегодно». В приговоре от 10 июня 1911 г. Федору Чурокаеву говорилось: «Уступить участок земли в количестве 25 десятин на местностях «Булун» и на местности «Арал» 10 десятин сроком на 30 лет с платою по 30 копеек за десятину. Он, Чурокаев, или его наследники имеют право возводить на арендованной земле все нужные постройки, как жилье, так и промышленные, а также производить посадки деревьев всех родов, засевать хлебом и заниматься скотоводством и выпасать таковой на киргизских землях, свободных от посевов хлебов; водой из арыка должен пользоваться беспрепятственно со стороны киргиз, участок этот находится на зимовых стойбищах киргиз нашей волости». За последний приговор Чурокаев уплатил манапу ${ }^{1}$ Монайтбасу Сартбаеву 220 рублей [ЦГА РК. Ф. 44. Оп. 1. Д. 15341. Л. 5,8$]$.

Данные приговоры свидетельствуют, что рамки общинного землепользования были тесны для зажиточных крестьян, не давали им развернуть свое хозяйство. Имея деньги, они хотели выйти из замкнутого общинного круга, являвшимся сдерживающим фактором для включения в хозяйствен-

${ }^{1}$ Представитель киргизской феодально-родовой знати. ный и предпринимательский круговорот. Поэтому Ф. Чурокаев и подобные ему крестьяне стремились жить самостоятельно.

Другим элементом, способствующим созданию хуторов, являлись переселенцы-самовольцы. Их не сразу наделяли землей и образовывали селения, и не всегда приписывали их к старожильческим селениям, поэтому они вынуждены были арендовать землю у кочевников и образовывать среди них хутора, но и такие попытки устроиться для них не всегда заканчивались удачно. Например, крестьяне селения Лебединского Пишпекского уезда Буханцевы арендовали участок земли у кыргызов Узунгырской волости, но Семиреченское областное правление не утвердило приговор, так как арендуемый участок вошел в состав запасного переселенческого участка «Мыскан», а закон воспрещал отвод в казну заарендованных земель для образования переселенческих участков. Товарищ (заместитель) министра внутренних дел разъяснял министру земледелия по данному поводу 13 апреля 1916 г.: «Принимая во внимание, что ко времени рассмотрения арендного приговора Общим присутствием, заарендованная земля уже вошла в границы переселенческого участка «Мыскан», вследствие чего общество киргизов потеряло свои права пользования и распоряжения означенной землей, надлежит признать, что приговор об аренде не мог получить утверждения Общего присутствия. Ввиду изложенного, министерство внутренних дел полагает постановление Общего присутствия Семиреченского областного правления за №3 от 21-25 января 1914 г. признать правильным, а жалобу крестьян Буханцевых оставить без последствий» [РГИА. Ф. 391. Оп. 6. Д. 477. Л. 8-8об.].

Этот случай свидетельствует, что крестьяне, прожившие на арендованной земле не менее года, все же могли выдворяться с данных наделов, а также о том, что вопросы землепользования переселенцев не были тщательно изучены и законодательно оформлены, отсюда и возникали различные казусные обстоятельства. Так, в ноябpe 1914 г. чиновники Главного управления земледелия и землеустройства Г. Глинка и Г. Чиркин писали Военному министру о том, что, согласно п. 2 ст. 31 Правил о переселении (1912 г.), «наделы переселенцев, хотя 
бы и оставшиеся без хозяев, самовольно покинувших места водворения, продолжают некоторое время числиться за таковыми, со всеми принадлежностями сих наделов - в частности и постройками - и по истечении года те же наделы получают новое, точное, определенное законом назначение - немедленное поступление в переселенческий земельный фонд» [РГВИА. Ф. 400. Оп. 1. Д. 4393. Л. 2].

Следует сказать, что закон об аренде земли не распространялся на лиц, не приписанных к обществам крестьян, т. е. на переселенцев-самовольцев, а самовольцы арендовали землю неофициально, т. е. незаконным путем.

Главное управление землеустройства и земледелия в апреле 1916 г. отмечало: «По имеющимся сведениям отдельные кибитковладельцы позволяют селиться разным лицам, не принадлежащим к киргизским обществам, на их землях, без совершения необходимых формальностей для аренды такой категории земель», в связи с этим циркулярно рекомендовало заведующему Государственными имуществами в Семиреченской области выдворять самовольцев с занятой или арендованной ими земли, так как в данном случае затрагивались интересы казны: самовольцы выплачивали поземельный налог не государству, арендная плата шла в карман киргизской верхушке. Далее рекомендовалось: «Если же самовольно поселившиеся окажутся на землях, изъятых в единственное владение казны, то с них надлежит требовать арендную плату по среднесправочным ценам на такие угодья в данном районе» [ЦГА РК. Ф. 784. Оп. 1. Д. 1104. Л. 13-13об.].

Несмотря на то, что крестьянская колонизация разрушала традиционную общинную систему землепользования, подворно-участковое землепользование не получило широкого распространения в Семиречье, что было связано с нехваткой свободной земли и, в связи с этим, обострением взаимоотношений переселенцев и кочевников. Именно поэтому главноуправляющий земледелием и государственными имуществами князь Б. А. Васильчиков, побывав в Семиречье, писал, что хуторскими участками среди «киргиз» переселенцы отказываются селиться и, зная положение дел, отмечал: «Да действительно, это теперь уже возможно может быть лишь вблизи существующих уже русских деревень, и то, при условии отобрания у киргиз части пахотных земель, которые сдаются в аренду» [ЦГА РУ. Ф. 1. Оп. 17. Д. 811. Л. 70].

А. А. Сапелкин указывает, что общинные земли не подвергались разделу из-за сопротивления крестьян, да и правительство, несмотря на закон от 14 июня 1910 г. об отрубах, не способствовало ликвидации общинного землевладения в крае, так как уже имело опыт разорения сельской общины в России [Сапелкин 1977: 22].

Сельская община являлась организацией крестьянства во всех ее проявлениях в общественной, хозяйственной, морально-психологической сферах и обеспечивала экономическую организацию деревни и интересы крестьянства. Тормозя социальноэкономическое развитие деревни и сохраняя сложившиеся в ней хозяйственные порядки и бытовые взаимоотношения, сельская община вместе с тем приспосабливалась к новым явлениям жизни переселенческой деревни.

Переселенцы не могли рассчитывать при аренде земли на содействие уездной администрации, так как она не имела права вмешиваться в эти дела. Копальский уездный начальник в январе 1907 г. писал заведующему переселенческим делом в Семиреченской области, что «общество каждой волости и отдельные лица всего общества сами входят в соглашение с арендаторами. Уездная администрация лишь рассматривает приговор об аренде, производит осмотр местности и дело предоставляет на рассмотрение и утверждение областного начальства» [ЦГА РК. Ф. 19. ОП. 1. Д. 1254. Л. 8].

Приговор киргизского волостного общества о сдаче земли в аренду русским крестьянам вступал в силу только с момента утверждения его Общим присутствием областного правления. Так, крестьяне села Лебединского Пишпекского уезда Наум, Егор и Иван Федянины жаловались на постановление Семиреченского областного правления от 10 ноября 1909 г., которым разрешалась сдача им «киргизских» земель на следующих условиях: 1) чтобы арендаторы не возводили на арендуемых участках жилых построек, кроме «необходимых для дела»; 2) чтобы в случае необходимости сдаваемая в аренду земля была возвращена в переселенческий 
фонд без вознаграждения за произведенные расходы; 3) чтобы арендаторы не переуступали арендованной земли другим лицам и не образовывали самовольческого поселка. Военный министр отменил постановление Семиреченского областного правления, как «вышедшее за пределы предоставленных ему законом прав по утверждению приговоров киргизских волостных съездов», так как включило в приговор требования, «крайне затрудняющие аренду киргизской земли русскими людьми вследствие полной необеспеченности договора найма» и не отвечающие ст. 126 Степного Положения [РГВИА. Ф. 400. Оп. 1. Д. 4331. Л. 8-9].

Во всех уездах Семиреченской области русские селения были довольно многочисленны. Вопрос о русской колонизации Туркестана приобрел особое значение с открытием работ по сооружению Оренбург-Ташкентской железной дороги, которая должна была обеспечить прибытие крестьян в край из губерний Европейской России. В июле 1900 г. царь распорядился устроить русские поселения вдоль направления железной дороги, возложив эту работу на особую экспедицию министерства земледелия и государственных имуществ, занятую подобного же рода работами в Степном крае. Изучение на местах этого вопроса было поручено командированному в Туркестан в 1900 г. директору Лесного департамента. Он пришел к выводу, что земельным фондом для русской колонизации края могут служить земли, занятые и используемые кочевниками. Но, за неимением сведений о землепользовании кочевников, он счел невозможным определить у них земельные излишки. Поэтому, по его мнению, чтобы «поставить землеотводное дело в Туркестанском крае на твердую почву, необходимо произвести специальное естественно-историческое и хозяйственно-статистическое исследование землепользования и быта кочевого населения» [РГВИА. Ф. 400. Оп. 1. Д. 3149], затем следует определить земельные излишки для русских поселений.

В 1900 г. министерство земледелия и государственных имуществ командировало в Тургайскую и Уральскую области особую экспедицию с целью точно определить свободные земельные излишки, которые предполагалось изъять из пользования кочевников для «надобностей» русской ко- лонизации. Туркестанские генерал-губернаторы С. М. Духовской и Н. А. Иванов соответственно в октябре 1900 г. и в марте 1901 г. обращались к министру земледелия и государственных имуществ А. С. Ермолову с просьбой распространить действие экспедиции на кочевые уезды Семиреченской области или командировать в область экономические и технические изыскательные партии, в обязанности которых должно входить образование земельных участков для переселенцев [РГВИА. Ф. 400. Оп. 1. Д. 3149. Л. 1-2, 12].

В связи с прибытием в 1902 г. в область огромного количества переселенцев, для их расселения в Семиречье требовалось большое количество земли, но свободной земли не было, если не считать двух путей: выселения «киргизов», замежевания их зимовок и пашен, а также строительства ирригационных сооружений и орошения новых земель специально для переселения. Общая площадь земель в Туркестане, к орошению которых уже приступили, доходила до 300 тыс. десятин. Кроме того, был составлен проект на орошение 1 млн. десятин земли [Статистический ежегодник 1924: 12].

Вся администрация Туркестанского края, начиная от уездного начальника до генерал-губернатора края, считала, что орошение пустующих земель - единственный путь к созданию переселенческого фонда. Ввиду постоянных представлений в министерство туркестанской администрации о том, что в Туркестане не имеется достаточного количества свободной земли, краевое чиновничество было взято под подозрение в «киргизофильских тенденциях», и была учреждена Туркестанская переселенческая организация, целью которой являлось создание переселенческого земельного фонда.

В начале XX в. аграрные волнения в России усилились. Правительство, стремясь снять накал социальной борьбы в центре, видело выход в расширении переселения крестьян на окраины страны. 25 июня 1903 г. были приняты «Правила о пособиях от правительства переселяющимся в Сибирь и Степное генерал-губернаторство», определяющие размеры пособий и льгот крестьянам-переселенцам. Переселенческая политика правительства обусловила необходимость открытия землеотводных работ в Туркестанском крае. В янва- 
pe 1904 г. при министерстве земледелия и государственных имуществ Государственным Советом России была сформирована Особая временная партия для образования переселенческих участков в Семиреченской области, на нужды которой было выделено 109090 руб., а именно: на производство землеотводных работ, так как в области к этому времени находилось 16 тыс. переселенцев-самовольцев, не наделенных землей. Заведующим партией для образования переселенческих участков в Семиреченской области был назначен титулярный советник Орест Авенирович Шкапский, ранее работавший в Сыр-Дарьинском областном правлении чиновником по сельскохозяйственной и оброчной частям [РГВИА. Ф. 400. Оп. 1. Д. 3243. Л. 7а, 21, 210].

Решение правительства об образовании переселенческой партии было обусловлено необходимостью скорейшего обустройства переселенцев-самовольцев из Европейской России, а также страхом перед возможными неурожаями в Сибири, что сулило огромный наплыв крестьян в Семиречье, привлекаемых обилием в нем хлеба и «пустопорожних» пространств с богатыми сельскохозяйственными угодьями и, пожалуй, главное - политическими соображениями - для упрочения русской власти в крае «ввиду близости Семиречья к Китаю и к фанатически настроенному населению Ферганы» [РГВИА. Ф. 400. Оп. 1. Д. 3158. Л. 5].

Основным занятием переселенцев было земледелие, которое велось как на надельной, так и на арендованной земле. Среди других видов хозяйственной деятельности можно выделить садоводство, огородничество, пчеловодство и скотоводство. Продукция животноводства и земледелия все чаще выходила на рынок, что создавало предпосылки для быстрого развития товарно-денежных взаимоотношений. Эффективная хозяйственная деятельность крестьян-старожилов сыграла важную роль в том, что Семиречье в силу своего экономического развития становится житницей всего Туркестанского края.

О. А. Шкапский писал, что богатство крестьян позволяет им нанимать киргизов. Он отмечал высокий экономический уровень крестьянских хозяйств переселенцев. Опираясь на данные о движении переселенцев в Копальском и Пишпекском уездах
Семиреченской области, О. А. Шкапский описывал случаи самовольного заселения территорий пришлыми крестьянами, отказывавшимися покидать приобретенные у казахов земли даже ради возврата своих средств. Он описывал случаи, когда сами киргизы, сдав переселенцам землю в аренду, становились батраками у своих арендаторов. О. А. Шкапский полагал, что необходимо было разработать четкие условия землепользования, а для этого требовалось иметь более или менее точные данные о составе местного населения и его хозяйственной деятельности, текущем положении сельского хозяйства, возможном будущем этого сектора экономики, всего земельного фонда [Белоус 2019].

Переселенческий закон 6 июня 1904 г. был попыткой выхода из создавшегося земельного кризиса. Закон объявлял свободу передвижения и даже устанавливал льготы сельским обывателям и мещанам, выселившимся в Азиатскую Россию. Кроме того, вопреки тяжелому положению в Семиречье, правительство, в связи с идеей специального переселения, рассчитывало значительную часть крестьян разместить в Туркестане. Для этой цели на 1905 г. Государственный Совет выделил 540 тыс. руб. на содержание и хозяйственно-операционные расходы, а также на «единовременные издержки по образованию Семиреченской партии» [РГВИА. Ф. 400. Оп. 1. Д. 3243. Л. 1а-5].

В 1905 г. Переселенческое управление было реорганизовано и присоединено к Главному управлению землеустройства и земледелия. В результате дело водворения переселенцев, отвод им земель, проведение гидротехнических работ были объединены в одной организации. В 1905 г. в Семиречье организуется Переселенческое управление, способствовавшее в полной мере изъятию земель у коренного населения.

Семиреченская переселенческая партия в срочном порядке приступила к созданию переселенческих участков из казахских земель. Однако землеотводные работы в Семиречье с 1906 по 1909 гг, когда необходимо было наделить землей пришедших в область самовольно 30-40 тыс. крестьян, велись недостаточно систематично. Обследование землепользования кочевников не дало результатов, так как за два года Особая переселенческая партия смогла изучить 
в естественно-историческом, гидротехническом и гидрогеологическом отношениях только две волости - Аламединскую и Толкановскую Пишпекского уезда. Такие темпы изучения области ни на шаг не продвинули вперед переселенческое дело, налицо были только расходы, так как содержание партии обошлось в сумму около 100 тыс. руб. [ЦГА РУ. Ф. И-1. Оп. 17. Д. 624. Л. 2 об.].

Военный губернатор Семиреченской области генерал-лейтенант М. Е. Ионов докладывал, что Переселенческая партия уклонилась от главной своей задачи, что она «спешит удовлетворить требования переселенцев о наделе их землею и приступает к созданию участков на избираемых самими переселенцами местностях, которые орошены киргизами, заняты ими под пашни, сады и зимовки».

В июне 1905 г. в Верненском уезде вспыхнуло недовольство среди самовольных переселенцев на «аграрной почве», и только после переформирования Семиреченской переселенческой партии оно затихло, но, по словам военного губернатора области, ненадолго [РГВИА. Ф. 400. Оп. 1. Д. 3485. Л. 2об., 36].

Остается догадываться, что послужило причиной «брожения». Скорее, это была коррупция в среде чиновников переселенческой партии за наделение крестьян требуемыми землями, крайне медленное проведение необходимых гидротехнических, топографических работ для образования переселенческих участков.

В канун столыпинской аграрной реформы начались очередные шаги по изучению земельных ресурсов Семиречья для продолжения крестьянских переселений. В 1906 г. в Семиречье был открыт Переселенческий район. В январе 1906 года Главным управлением землеустройства и земледелия в область для «заведывания на местах переселенческим делом, объединения деятельности землеотводных и гидротехнических партий и местных переселенческих организаций» [ЦГА РК. Ф. 44. Оп. 1. Д. 2529. Л. 1] был командирован чиновник особых поручений при Переселенческом управлении Сергей Николаевич Велецкий.

В 1906 г. было исследовано 6 волостей в Пишпекском уезде, в Верненском - 3, в 1907 г. было исследовано уже 8 волостей Лепсинского уезда и 1 волость - Копальского, в 1908 г. в Копальском уезде исследо- вано было уже 6 волостей, в Пржевальском и Джаркентском уездах - по 8 волостей в каждом [РГИА. Ф. 391. Оп. 3. Д. 1354. Л. 1-1об., 43, 50].

С. Н. Велецкий считал, что идти дальше «по пути сокращения киргизского хозяйства», т. е. вытеснения с законной земли, «положительно невозможно» [РГИА. Ф. 391. Оп. 3. Д. 124. Л. 22-22об.]. «Но, отмечал С. Н. Велецкий, - окончательное устройство киргиз неминуемо поднимает вопрос об окончательном наделении старожилов, крестьян и казаков» [РГИА. Ф. 391. Оп. 3. Д. 1344. Л. 30об.], поэтому необходимо было детальное изучение землепользования кочевников, казаков и всех категорий крестьян-переселенцев.

В 1909 г. правительством было решено провести в Семиреченской области подробное статистико-экономическое обследование. Заведующим статистическими работами в Семиречье был назначен статистик Петр Петрович Румянцев. Основной задачей предпринимаемого обследования являлось выяснение условий и количественный учет землепользования казахов-кочевников, а также определение типов их хозяйства, что позволило вывести нормы земельного обеспечения кочевых хозяйств и определить земельные излишки, которые образовались бы при наделении землей кочевников по этим нормам. Однако статистическое обследование области проводилось в 19091913 гг., а обработка этих статистических данных завершилась лишь в 1916 г. Вопрос официального наделения крестьян землей так и не был решен на государственном уровне, а проводился в основном спонтанно и, по большей части, силами самих переселившихся крестьян, что создало нездоровую социально-психологическую обстановку в регионе и привело к восстанию населения Центральной Азии и Казахстана в 1916 г.

Выводы. Таким образом, анализ фактического материала по изучаемой проблеме позволяет произвести следующие выводы. Семиречье в Российской империи являлось важным регионом, предназначенным для русской крестьянской колонизации. К этому побуждали российское правительство не только интересы хозяйственного освоения благодатного края, не только необходимость снижения «земельного голода» в Европейской России, но и политическая стратегия. 
Основным занятием крестьян-переселенцев в Семиречье являлось растениеводство (зерновое производство, садоводство, огородничество). Животноводство, бывшее основным занятием кочевников, у русских крестьян являлось второй отраслью. Это порождало сложность решения правовых вопросов землеустройства переселенцев. Также рост переселенческого движения в Семиречье явился одной из причин самовольных захватов земель в регионе, что обусловило появление наряду со старожильческими селами новоселий и самовольных поселков. Данное обстоятельство явилось основой для дальнейшего усложнения землеустроительных мероприятий в Семиречье и возникновения земельных конфликтов. В ходе проведения переселенческой политики в регионе администрация была озабочена прежде всего поиском земельных излишков у кочевников. Однако неясность землеустроительной картины в регионе вынудила администрацию произвести широкое статистико-экономическое обследование Семиречья для проведения последующих землеотводных работ. Эта деятельность была актуализирована необходимостью проведения столыпинского землеустройства в Российской империи. Следует признать, что в дореволюционный период определение правовых основ землевладения и землепользования переселенческого населения в Семиречье так и не было завершено.

\section{Источники}

Обзор 1884 - Обзор Семиреченской области за 1883 г. Верный: Тип. Семиреч. обл. правления, 1884. 96 с.

РГВИА - Российский государственный военно-исторический архив.

РГИА - Российский государственный исторический архив.

Статистический ежегодник - Статистический ежегодник. 1917-1923 гг. / сост. под ред. Д. П. Красновского. Ташкент, 1924. Т. 1.

ЦГА РК - Центральный государственный архив Республики Казахстан.

ЦГА РУ - Центральный государственный архив Республики Узбекистан.

\section{Sources}

[Review of Semirechye Oblast: 1883]. Verniy: Semirechye Oblast Executive Office, 1884. 96 p. (In Russ.)
Russian State Archive of Military History.

Russian State Historical Archive:

[Statistical Yearbook: 1917-1923]. D. P. Krasnovsky (ed.). Tashkent, 1924. Vol. 1. (In Russ.)

Central State Archive of the Republic of Kazakhstan. Central State Archive of the Republic of Uzbekistan.

\section{Литература}

Абдиров, Актамбердиева 2011 - Абдиров М. Ж., Актамбердиева 3. С. Семиреченское казачье войско. Из истории военно-казачьей колонизации Жетысу 1867-1917 гг. Алматы: Қазақ унивеситеті, 2011. 362 с.

Аристов 2003 - Аристов Н. А. Труды по истории и этническому составу тюркских племен / отв. ред. акад. В. М. Плоских. Бишкек: Илим, 2003. 460 c.

Бартольд 1963 - Бартольд В. В. История культурной жизни Туркестана. Соч. Т. 2. Ч. 1. М.: изд-во восточной лит-ры, 1963. С. 169-434.

Бекмаханова 1986 - Бекмаханова Н. Е. Многонациональное население Казахстана и Киргизии в эпоху капитализма (60-е годы XIX в. - 1917 г.). М.: Наука, 1986. 246 с.

Белоус 2019 - Белоус С. Г. О. А. Шкапский об аграрной политике в казахской степи в конце XIX - начале XX вв. [электронный ресурс] // Электронный научный журнал «edu.ehistory.kz». 2019. № 2(10). http://edu.e-history. kz/ru/publications/view/678 (дата обращения: 10.10.2019).

Далаева 2012 - Далаева Т. Т. Земельная политика Российской империи в Южном Казахстане и Семиречье во второй половине XIX века // История Казахстана: современные исследования и актуальные проблемы преподавания. Мат-лы Республ. науч.-практ. конф. «Касымбаевские чтения». Алматы: Улагат, 2012. С. 198-202.

Забиров 1958 - Забиров К. Переселение и колонизация Северной Киргизии // Ученые записки исторического факультета КГУ. Вып. VI. 1958. 147-151 с.

Ильясов 1963 - Ильясов С. И. Земельные отношения в Киргизии в конце XIX - начале XX в. Фрунзе: изд-во АН Кирг. ССР, 1963. 447 с.

Кауфман 1905 - Кауфман А. А. Переселение и колонизация. СПб.: Тип. т-ва «Общественная польза», 1905. 443 с.

Логанов 1909 - Логанов Г. Россия в Средней Азии // Вопросы колонизации. 1909. № 4. C. 1-77.

Мийманбаева 2002 - Мийманбаева Ф. Н. Русские переселенцы в Семиречье в конце XIX - начале XX в. Алматы, 2002. 50 с. 
Пален 1910 - Пален К. К. Переселенческое дело в Туркестане / Отчет по ревизии Туркестанского края, произведенной по высочайшему повелению сенатором гофмейстером графом К. К. Паленом. СПб.: Сенат. тип., 1910. $430 \mathrm{c}$.

Румянцев 1911 - Румянщеев П. П. Условия колонизации Семиречья // Вопросы колонизации. 1911. № 9. С. 191-224.

Сапелкин 1977 - Сапелкин А. А. Аграрные отношения в Киргизии в начале ХХ в. Фрунзе: Илим, 1977. 281 с.

Сатенова 2019 - Сатенова М. Р. Основные аспекты земельной политики российской администрации в Семиреченском крае (вторая половина XIX века) [электронный ресурс] // Электронный научный журнал «edu.ehistory.kz» № 1. 2019. http://edu.e-history.kz/ ru/publications/view/149 (дата обращения: 15.08.2019).

Шкапский 1907 - Шкапский О. А. Переселенцы-самовольцы и аграрный вопрос в Семиреченской области // Вопросы колонизации. 1907. № 1. C. 1-32.

Graham 1916 - Graham S. Through Russian Central Asia. London; New York; Toronto; Melbourne: Cassell and Company, Ltd, 1916. 279 p.

\section{References}

Abdirov M. J., Aktamberdyeva Z. S. [Semirechye Cossack Host: Glimpses of the 1867-1917 Military Cossack Colonization of Zhetysu]. Almaty: Al-Farabi Kazakh National University, 2011. 362 p. (In Russ.)

Aristov N. A. [Works on the History and Ethnic Composition of Turkic Tribes]. V. M. Ploskikh (ed.). Bishkek: Ilim, 2003. 460 p. (In Russ.)

Barthold V. V. Turkestan: history of cultural life. In: [Collected Works]. Vol. 2. Part 1. Moscow: Vostochnaya Literatura, 1963. Pp. 169-434. (In Russ.)

Bekmakhanova N. E. [Multinational Population of Kazakhstan and Kyrgyzstan in the Capitalist Era: 1860s - 1917)]. Moscow: Nauka, 1986. 246 p. (In Russ.)

Belous S. G. O. A. Shkapsky about agrarian policy in the Kazakh steppe at the end of XIX - the beginning of the $\mathrm{XX}^{\text {th }}$ centuries. Scientific
E-journal «edu.e-history.kz». 2019. No. 2 (10). An Internet resource: http://edu.e-history.kz/ru/ publications/view/678 (accessed: October 10, 2019). (In Russ.)

Dalaeva T. T. Land policy of the Russian Empire in Southern Kazakhstan and Semirechye in the mid-to-late $19^{\text {th }}$ century. In: [History of Kazakhstan: Contemporary Studies and Topical Issues of Teaching]. Conf. proc. Almaty: Ulagat, 2012. Pp. 198-202. (In Russ.)

Graham S. Through Russian Central Asia. London; New York; Toronto; Melbourne: Cassell and $\mathrm{C}^{\circ}$ Ltd, 1916. 279 p. (In Eng.)

Ilyasov S. I. [Land Relations in Kyrgyzstan: Late $19^{\text {th }}$ - Early $20^{\text {th }}$ Centuries]. Frunze: Kyrgyzstan Academy of Sciences, 1963. 447 p. (In Russ.)

Kaufman A. A. [Resettlement and Colonization]. St. Petersburg: Obshchestvennaya Polza, 1905. 443 p. (In Russ.)

Loganov G. Russia in Central Asia. Voprosy kolonizatsii. 1909. No. 4. Pp. 1-77. (In Russ.)

Miymanbaeva F. N. [Russian Settlers in Semirechye: Late $19^{\text {th }}-$ Early $20^{\text {th }}$ Centuries]. Almaty, 2002. 50 p. (In Russ.)

Palen K. K. [Resettlement Case in Turkestan: Report on the Audit of Turkestan Region Compiled by Senator K. K. Palen]. St. Petersburg: Governing Senate, 1910. 430 p. (In Russ.)

Rumyantsev P. P. Conditions of colonization in Semirechye. Voprosy kolonizatsii. 1911. No. 9. Pp. 191-224. (In Russ.)

Sapelkin A. A. [Agrarian Relations in Kyrgyzstan by the Early $20^{\text {th }}$ Century]. Frunze: Ilim, 1977. 281 p. (In Russ.)

Satenova M. R. Key aspects of the Russian administration's land policy in Semirechye (2-nd half of the XIX century). Scientific E-journal «edu.e-history.kz». 2019. No. 1. An Internet resource: http://edu.e-history.kz/ru/ publications/view/149 (accessed: August 15, 2019). (In Russ.)

Shkapsky O. A. Self-willed immigrants and the agrarian question in Semirechye Oblast. Voprosy kolonizatsii. 1907. No. 1. Pp. 1-32. (In Russ.)

Zabirov K. Resettlement policies and colonization of Northern Kyrgyzstan. In: [Faculty of History, Kyrgyz State University: Scholarly Notes]. Vol VI. Frunze, 1958. Pp. 147-151. (In Russ.) 